\author{
TEOR TOTAL DE FENÓLICOS E ANTOCIANINA DE DOIS CULTIVOS DE UVA VERMELHA \\ (VITIS VINIFERA L.) CVS SAHEBI E HALAGHO CONFORME AFETADOS PELA SEVERIDADE \\ DA PODA E COMPRIMENTO DA CANA
}

\title{
TOTAL PHENOLICS AND ANTHOCYANIN CONTENT OF TWO RED GRAPE (VITIS VINIFERA L.) CVS SAHEBI AND HALAGHO CULTIVARS AS AFFECTED BY PRUNING SEVERITY AND CANE LENGTH
}

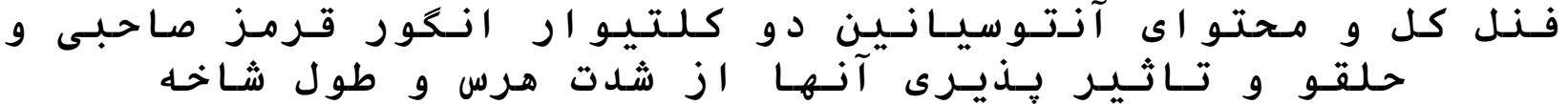

\section{MAHTAB, Zonouri ${ }^{1}$; DAVOOD, Bakhshi2*; ESMAEIL, Fallahi ${ }^{3} ;$ ISA, Arji ${ }^{4}$}

${ }^{1}$ University of Guilan, Faculty of Agricultural Sciences, University Campus 2, Department of Horticultural Science

${ }^{2}$ University of Guilan, Faculty of Agricultural Sciences, Department of Horticultural Science

${ }^{3}$ University of Idaho, Parma Research and Extension Center, Parma

${ }^{4}$ Agricultural and Natural Resources Research and Education Center, Department of Crop and Horticultural Science Research

* Corresponding Author

e-mail: bakhshi-d@guilan.ac.ir

Received 06 August 2019; received in revised form 20 September 2019; accepted 28 October 2019

\begin{abstract}
RESUMO
Uma uva popular e importante a 'Sahebi' e uma uva local menos conhecida a 'Halagho' do Irã foram estudadas para desmascarar a influência da severidade da poda e do comprimento da cana nos potenciais bioativos da fruta; teor total de fenólicos e antocianinas nas quais eles afetaram significativamente. Nesta investigação, foram estudados os efeitos de 4, 6 e 8 gemas por cana com intensidade de poda leve, moderada e severamente podada e sua interação no curso de dois anos consecutivos, 2017 e 2018 nas variedades 'Sahebi' e 'Halagho'. Os resultados revelaram diferenças marcantes que, em qualquer cultivar, o conteúdo fenólico da polpa foi 2 a 5 vezes maior em 2017 em comparação com 2018 com a 'Halagho' severamente podada no mais alto $(5,14 \mathrm{mg} / \mathrm{g} \mathrm{DW})$. Considerando que 'Halagho' podada levemente com 6 gomos por cana teve o maior conteúdo de antocianina da casca (1,09 mg/g DW), na mesma condição, mas com a poda severa 'Halagho' apresentou o maior conteúdo de antocianina na polpa $(0,86 \mathrm{mg} / \mathrm{g} \mathrm{DW})$ enquanto no segundo ano, em 2018 , podada severa ou levemente esse tipo com 6 gemas por cana teve um aumento significativo no acúmulo de compostos fenólicos (10 mg/g DW). A partir dos resultados deste experimento, pode-se concluir que a poda das videiras é um estressor e gera fitoquímicos aprimorados que podem possivelmente mitigar as consequências negativas. No entanto, a variação nas propriedades bioquímicas manifestou uma dependência notável da cultivar de uva, além do fator tempo, que foi mais pronunciado na variedade 'Halagho' do que na 'Sahebi'. Até certo ponto, o efeito das cultivares foi predominante nas diferenças de duas cultivares.
\end{abstract}

Palavras-chave: polpa de bagas; qualidade da baga; casca das bagas; fecundidade de brotos; fitoquímicos.

\begin{abstract}
A popular and important grape 'Sahebi' and a less known local grape 'Halagho' in Iran, were studied to unmask the influence of pruning severity and cane length on fruit bioactive potentials; total phenolic and anthocyanin content in which they affected significantly. In this investigation, effects of 4,6 and 8 buds per cane with pruning intensity as light, moderate and severely pruned and their interaction in the course two consecutive years, 2017 and 2018 in 'Sahebi' and 'Halagho' were studied. Results revealed striking differences which in either cultivar, pulp phenolic content was 2 to 5 fold higher in 2017 compared to 2018 with the severely pruned 'Halagho' at the highest $(5.14 \mathrm{mg} / \mathrm{g} \mathrm{DW})$. Whereas, lightly pruned 'Halagho' with 6 buds per canes had the highest peel anthocyanin content $(1.09 \mathrm{mg} / \mathrm{g} \mathrm{DW})$, in the same condition but with severely pruning 'Halagho' showed the highest anthocyanin content in pulp $(0.86 \mathrm{mg} / \mathrm{g} \mathrm{DW})$ while in the second year, 2018 , severely or lightly pruned this type with 6 buds per cane had a significant increase in phenolic compound accumulation $(10 \mathrm{mg} / \mathrm{g} \mathrm{DW})$.
\end{abstract}


From the results of this experiment, it could be concluded that the pruning of the vines is a stressor and generates enhanced phytochemical constitutes to possibly mitigate the negative consequences. However, variation in the biochemical properties manifested a notable grape cultivar dependency in addition to the time factor, which was more pronounced in 'Halagho' than 'Sahebi'. To some extent the effect of cultivars on the differences of two cultivars was predominant.

Keywords: berry pulp; berry quality; berry peel; bud fruitfulness; phytochemicals

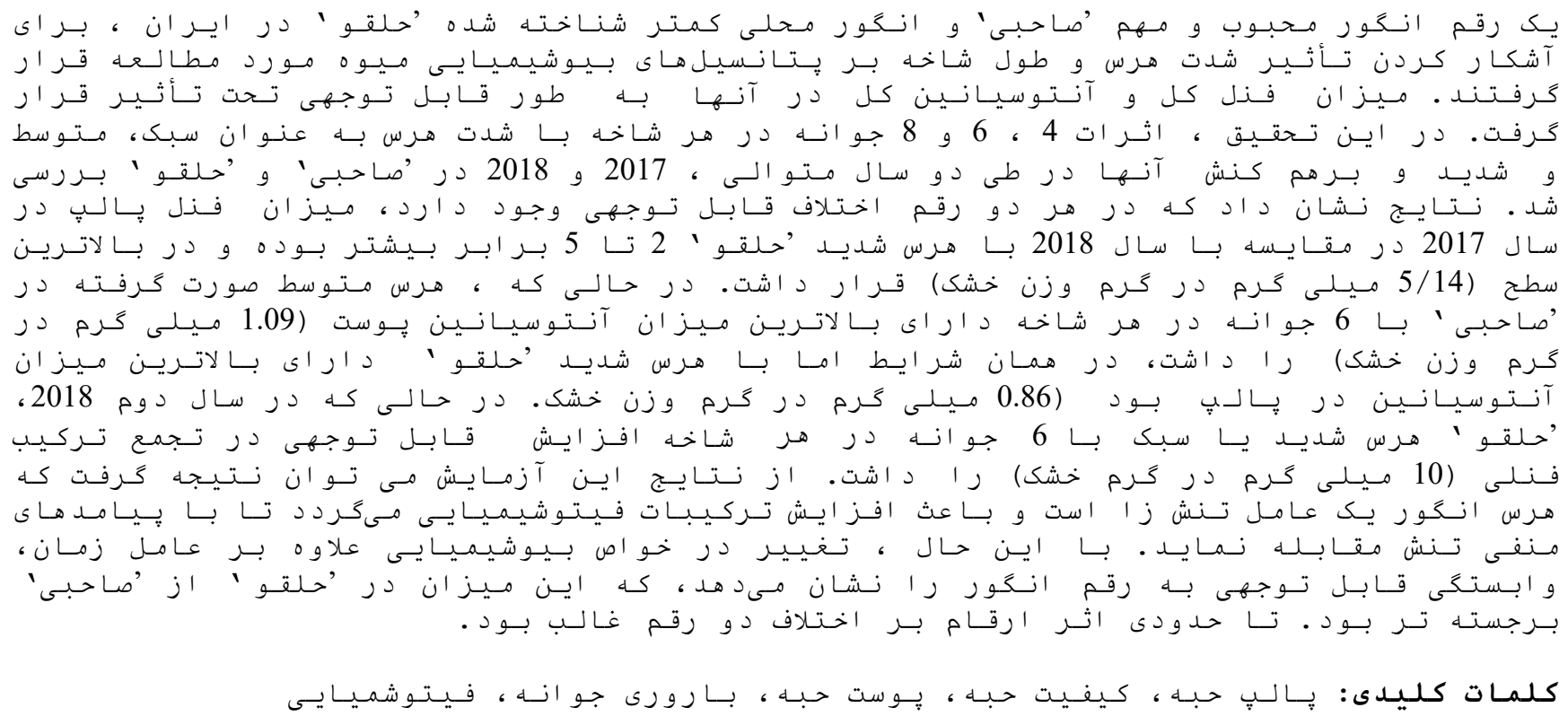

\section{INTRODUCTION}

Grapevine (Vitis vinifera L.) is one of the most valuable agricultural crops worldwide. Archeological and historical discoveries suggest the Near-East region between the Black and Caspian seas where its early domestication could have been taken place (Myles et al., 2011).

The very first traces of grape cultivation detected in the north of Zagros mountains-Iran (McGovern, 2017). Considering the criticality of grape fruit, knowledge on almost every aspect in particular secondary metabolites in grapevine is expanding which helps vine growers to develop new cultivation techniques to modify and improve grape quality (Azuma, 2018). From which plant management can significantly contribute to improving viticultural practices in order to control plant physiological response, reflecting on enhancement table grape yield and quality. As a key task, pruning remains a manual operation that can largely influence a spectrum of quality and quantity properties (Billikopf and Norton, 1992; Keller, 2015).

As mentioned earlier, pruning is a cultural task with multidimensional effects which improving bud fruitfulness by selecting buds in appropriate positions as well as control of shoot numbers and their placement of vine and enhancement of fruit quality in general and lessening the fluctuation in average annual yield in long-term (Groumpos et al., 2015). Moreover, grapes enriched of an array of phenolic constitutes in the peel, seeds, and pulp which possess notable biological properties specifically antioxidant activity (Casazza et al., 2010). Being known for high nutritional and health values, fresh grape consumption is experiencing a significant and constant increase. In fresh fruits, texture and color attributes for the assessment of freshness and enjoyment of eating (Peneau et al., 2006).

Also, the peel of the red grape compose of a large number of phytochemicals, because polyphenolics specifically anthocyanins in berry distributed unevenly with main concentration in peels (Adams, 2006; Godevac et al., 2010) which confers numerous health benefits (Zhang et al., 2011), and since all phenolics contain at least one aromatic ring, they can consequently absorb UV light effectively (Cote et al., 2010). The grape polyphenol compounds are chiefly classified as 
flavonoids (C6C3C6 skeleton) with a high level of anthocyanins (Garrido and Borges, 2013). Owing to their capability in quenching oxidants, anthocyanins are found to be accumulated in response to myriad number of environmental stresses (Braidot et al., 2008; Song et al., 2015). Additionally, they are potent bioactive constitutes with anti-inflammatory and anticancer activities (Xia et al., 2010).

The quantification of the quality traits of the grapevine can indeed provide viticulturists with invaluable practical knowledge, enable them to operate field tasks in a more efficient manner which ultimately leads to higher yield and filling the gap between supplies vs. demand (Barbagallo et al., 2011). The concentration and composition of phenolic compounds in red grapes differ with grape cultivars (Costa et al., 2014). In mountain vineyards, vines are trained by the head training systems, which due to its cost-effectiveness as well as low maintenance requirement is economically feasible. The lack of incident radiation in the clusters and excessive crop loads decrease quality.

Iran is one of the renown producers of table grapes and processed products such as juice and raisin in the world (FAO, 2014). Having an enormous variability of grapes in Iran, now various local grape cultivars being bred, albeit so far no significant attention on behalf of scholars has been paid to them. As a case in point, there is no published report concerning the berry phenolic content of 'Halagho' and 'Sahebi' grapes, native red grape cultivars which the former cultivar mostly coltivated in the west of Iran while the later cultivar is popular and coltivated widly. Hence, the purpose of current research was to evaluate the phenolic content and total anthocyanins of berries of those two abovementioned cultivars in the full ripening stage (e.g., in various parts: peel, pulp, and whole berry) to explore the effects of combined pruning severity and different bud numbers per cane in common vineyard conditions.

\section{MATERIALS AND METHODS}

\subsection{Site description}

The experiment was carried out in two consecutive growing seasons, 2017 and 2018, in a commercial vineyard located in Sarbarzeh region of Kermanshah province, in the west of Iran (34 $45^{\prime} 46 " \mathrm{~N} ; 4^{\circ} 11^{\prime} 34^{\prime \prime} \mathrm{E}, 1923 \mathrm{~m}$ asl). Two seeded red table grape varieties,'Sahebi' and 'Halagho' from 20 year-old vines with head training at a spacing of 1.5 by $2.5 \mathrm{~m}$ in an eastwest row orientation in a relatively equal status were used. Both cultivars were hardwood cutting-originated, irrigated with drip irrigation. During each phenological period the irrigation applied in addition to possible precipitation.

\subsection{Pruning programs}

The 20 years old vines that annually moderately pruned by the owner in this study defined as 'control'. Our concentration in this experiment was on exploring the possible impacts of the length of canes and the severity of pruning. Pruning plan was applied in late - Apr in 2017 and late- Mar in 2018 (Because of local weather conditions. Pruning severity treatments have consisted of two types of pruning; lightly pruned with the formula $40+20$ and severely pruned with $20+20$ formula (Ahmedullah and Himelrick, 1989). Afterward, in the number of buds per cane, substitute cane (two-node spur) were pruned with 2 bud lengths and by randomly with respective treatments: pruning, 4,6 and 8 buds on the cane and different pruning intensity of light and intensity). To repeat this experiment in 2018, the substitute canes (two-node spur) pruned and each on cane, two buds remained exchanged.

\subsection{Sampling}

Specimens were collected at the berry fully ripe stage, based on the red color appearance. Picking grape bunches was carefully randomized throughout the vines for each cultivar. Vines were well managed, uniform in size, and had no nutrient deficiency or pest damage. At least 10 cluster samples were taken from each vine.

\subsection{Biochemical analyzes}

\subsubsection{Fruit material and extract preparation}

Briefly, grape samples were manually separated into peel and seeds. Berries were cut longitudinally with a razor blade, and seeds were carefully removed from each berry. The pulp on the inner face of berry peel was removed using an end-flattened spatula. Peel of freshly harvested grapes was directly separated, weighed and then pulverized with liquid nitrogen to ensure full phenolic extraction. Of each specimen $500 \mathrm{mg}$ was mixed with $1.5 \mathrm{ml}$ solvent containing $85 \%$ methanol and $15 \%$ acetic acid. Mixtures then incubated at $4{ }^{\circ} \mathrm{C}$ in the dark for 24 h. The extracts were centrifuged at $10000 \mathrm{rpm}$ for 10 min, using Whatman filter papers the solvents removed from the extracts. The mixtures stored at $4{ }^{\circ} \mathrm{C}$ before use. 


\subsubsection{Total phenolic content}

Total phenolic content (thereafter; TPC) in the grape extracts were evaluated colorimetrically according to the Folin-Ciocalteu colorimetric method (Singleton and Rossi, 1965) with slight modification. Briefly, $70 \mu \mathrm{l}$ the grape extracts were mixed with $1 \mathrm{ml}$ Folin-Ciocalteu reagent $10 \%$, then added to $130 \mu \mathrm{l}$ double distilled water. After $6 \mathrm{~min}, 7.5 \%$ sodium carbonate solution was added. The mixture was allowed to react at room temperature in the dark for $90 \mathrm{~min}$, and then, the absorbance was measured at $760 \mathrm{~nm}$. The results were expressed as milligrams of gallic acid equivalents (GAE) per gram dry weight. Gallic acid was employed as a calibration standard. The measurements were compared to a standard curve of prepared gallic acid solutions and expressed as mg gallic acid equivalents per gram dry weight (GAE/g DW) $\left(y=3.0912 x+0.0502, y^{2}=9962\right)$ of peel and pulps. The standard curve was generated with 0.10 , $0.20,0.30$ and $0.40 \mathrm{mg}$ gallic acid/L by a UV-vis double-beam spectrophotometer (T80+UV/VIS PG Instrument Ltd) at the wavelength of $750 \mathrm{~nm}$.

\subsubsection{Total anthocyanin content}

Using Wrolstad (1976) method with some change the total anthocyanin content (thereafter; TAC) was measured. The absorbance of the anthocyanin containing extract, described above, was then measured at 520 and $700 \mathrm{~nm}$ in two reference $\mathrm{pH} 1.0$ and 4.5 buffers against a blank of reagents according to Longo and Vasapollo (2006). The calculation of cyanidin 3glucoside (C3G) was done using Equations 1 and 2.

$A=\left(A_{510}-A_{700}\right)$ pH $1.0-\left(A_{510}-A_{700}\right)$ pH 4.5 (Eq. 1)

TMA content $=(\Delta \mathrm{A} \times \mathrm{MW} \times \mathrm{DF} \times \mathrm{Ve} \times 1000) /(\varepsilon$ $\times 1 \times C)$

Where $A$ is absorbance, MW is the molecular weight of cyanidin-3-glucoside (449.2), DF is the dilution factor (1), Ve is the extract volume, $\delta$ is the molar absorptivity coefficient of cyanidin-3-glucoside $(29,600)$, and $M$ is the mass of the berries extracted and $C$ is the concentration of the grape extract in milligrams per milliliter. The final results expressed as $\mathrm{mg} / \mathrm{g}$ DW of anthocyanin.

\subsection{Statistical analysis}

The experimental design used was a split-split plot with three replicates. The main factors consisted of time (year) with two levels (2017 and 2018) and grape cultivars with two levels ('Sahebi' and 'Halghoo'). The severity of pruning (light, moderate and severe) was considered as sub-plot factor and number of buds per cane (4, 6, 8 buds per cane) as sub-sub (or split-split) factors. Analysis of variance was performed using the SAS statistical package (version 9.4; SAS Institute, Cary, NC, USA). Differences among treatments were assessed by Duncan's range test at the level of $1 \%$ and $5 \%$.s

\section{RESULTS AND DISCUSSION}

A notably valuable insight into the impacts of pruning practice on phytochemical contents of two important Iranian red grapes was acquired, in which in terms of time factor the TPC of the grape peel, as well as pulps in either cultivar, was significantly higher in 2017 than 2018, by comparison (Table 1 and 2). Interestingly enough, TPC of the whole berry in 2018 was significantly higher when compared with 2017 (Table 3). Whereas to some extent, similar to the TPC behavior pattern, in 2017, TAC of peel, pulp, and whole berry was higher in 2017 than in 2018 (Tables 4, 5 and 6). In 2017, as negative consequences of pruning, imposing stress, and significant decrement in yield and fruit size by comparison to control were witnessed.

By 2018, vines reached stable physiological conditions, which as a result, enhancement in fruit growth was observed. Increasing the amount of phenolic compounds in peel and pulp in 2017 compared to 2018 can also be justified by the fact that due to increased light penetration into the crown of vines, in all forms of pruning severity light, moderate and severe.

Archer and Strauss (1989) reported that the fruit composition is affected by the microclimate inside the crown, in shade conditions, the quality of fruit in grapes is greatly reduced. In fact, with the increase of light penetration into the vines, phenolic compounds increased in 2017, but in 2018, by creating a coating on grape fruit clusters, reduced light intensity and phenolic compounds decreased. The phenolic content was significantly lower in the grape pulp when compared with peel (Table 2). The content of phenolics seems to be a tissue specific trait. Phenolics were lower in pulp compared to peel which is in accordance with other scholars (Pantelic, 2016), unlike pulp, the grape peel contains a large array of phenolic compounds (Nile et al., 2013). The accumulation of secondary metabolites is a strategy of plant 
defense against stress.

Vine response to stress at the berry level resulted in the accumulation of secondary metabolites in pulp and peel as a defense against cell degradation (Ferrandino and Lovisolo, 2013).

On the other hand, considering the fact that parameters such as yield, TSS, TA and number of berries per bunch showed a statistically significant increase in 2018 (data not shown), hence, it could be pointed that increase in volume of yield may lead to lessen the concentration of phytochemicals of interests in this experiment. In 2017, peel phenols of 'Sahebi' were significantly lower than 'Halagho' in all pruning levels and number of buds per cane (Table 1).

Differences in the phenolic compounds of various grape cultivars have also been proven in others' studies (Rodriguez-Montealegre, 2006; Orak, 2007; Pantelic, 2016). The grape cultivar exerts a significant influence on the phenolic composition (Dani et al., 2007; De Pascali et al., 2014). The concentration and composition of phenolic compounds in red grapes differ with grape cultivars (Costa et al., 2014).

In which in this study regardless of the factor of year, the two grapes type almost followed a consistant pattern since the compounds targeted in 'Sahebi' where lower in general when capered to 'Halagho'. The difference in phenolic contents in the peel of cultivated grapes couldbe partly attributed to the genotypes (Montealegre et al., 2006).Peel morphological and structural characteristics, as dictated by the cultivar, seem to exert a direct effect on the extractability of phenolic compounds (Rolle et al., 2009). Biochemically, flavonoids and anthocyanins are important determinants of antioxidant capacity and quality of fruit.

Acylated derivatives of anthocyanin greatly affect its stability and color intensity. In this study, there was a significant difference between the anthocyanin and phenol compounds in 'Halagho' and 'Sahebi', indicating the genetic difference and the enzymes involved in the bio production of the compounds in different cultivars reported by other researchers (Yonekura-Sakakibara, 2009).

Severe and moderate pruning of 'Halagho' during 2018 lead to a significant increase in TPC in the whole berry. In 2017, severely and lightly pruned of 'Sahebi' compared with control treatment, and maintenance of 4,6 or 8 buds per cane showed a significant decrease in total phenol content in the whole berry which showed no significant difference at all (Table 3).

In the case of the interaction between years, grape cultivars, pruning severity and the number of buds per cane showed that 'Halagho', when pruned in 2017 with 6 or 4 buds per cane, showed peel anthocyanin content which was not significantly affected by treatments. In 2018, peel anthocyanin content in both cultivars decreased without any significant difference (Table 4). In severely pruned 'Halagho' in 2017 and the maintenance of 6 buds per cane increased pulp anthocyanin significantly compared to other treatments.

The pulp anthocyanin in both cultivars decreased significantly in 2018 (Table 5). Severe pruning of 'Sahebi' in 2017 with 4 buds per cane increased TAC in the whole berry which was not significantly different from the other treatments. In 2018, TAC was significantly decreased in both cultivars compared with 2017. However this difference was not significantly different (Table 6 ). The results of this experiment indicated that the pruning of two cultivars, 'Halagho' and 'Sahebi' (in particular the 'Halagho'), in 2017, increased anthocyanin content in the peel, pulp, and whole berry as compared in 2018. In all pruning levels, a self-regulating branch growth was found leading to an increase in compounds such as anthocyanin and total phenols. In red grapes, such as 'Halagho' and 'Sahebi', anthocyanins are an important group of phenolic compounds (Yang et al., 2009) because of their valuable nutritional and medicinal benefits and visual quality of their color. The peel color plays an important role in determining fruit quality of table grapes, mainly due to the composition and the content of anthocyanins (Paredes-Lopez et al., 2010). It is shown that the quantity and quality of anthocyanins in grape berries greatly influence the quality of red grapes (Boss et al., 1996). Phenolics in the plant kingdom are important because of their function in the defense system. Pruning has a significant effect on the accumulation of these compounds. In order to synthesize anthocyanin in grapevine berries and to balance juice compounds, clusters should receive direct sunlight (Spayd et al., 2002). Due to the high temperature for producing high quality fruits and berries with maximum color, it should be prevented from exposing clusters to long-term exposure to sunlight (Bergqvist et al., 2001). In confirmation of this point, the results of this research showed that the pruning of the 
'Halagho' in light form in 2017 and keeping 6 buds per cane or the severe pruning of this cultivar in 2017 and keeping 4 buds per cane increased anthocyanin content in the peel. These results are consistent with reports from Shinomiya et al. (2015). Vine or cluster exposure to low temperature and high light intensity enhances anthocyanin accumulation which was not seen in the current work. This might be due to the training system used in this study. High temperature and/or shading treatments reduce berry peel coloration. Reports of increasing anthocyanin accumulation due to sunlight exposure have helped growers to avoid poor peel coloration by incorporating light quality control methods, such as shoot positioning and light reflectors around the fruiting zone. In a vineyard, the training system determines the light interception for a certain amount of leaf area and consequent bud and fruit exposure to sunlight (Reynolds and Heuvel, 2009). Bunch sunlight and UV exposure significantly increase anthocyanins content in the grape (Song et al., 2015). In particular, temperature and irradiance are critical because of their direct effect on the synthesis and accumulation of polyphenols in the berries (Keller, 2010). The effects of light on grapevine physiology have been exploited to address grape berry quality: different training systems, influencing the vine light use efficiency exert pivotal consequences on berry quality (Petrie et al., 2009).

The reduction of the anthocyanin level in 2018 can also be due to branch growth. The anthocyanin levels in the whole berry, pulp and peel are significantly lower than in 2017 . It has been proved that phenolic biosynthesis may be induced in response to different abiotic elicitors (Song et al., 2015). In 2017, the number of canes was reduced due to differences in pruning intensity compared to 2018 . The number of cane per plant in the year 2016 was significantly higher than in 2017 and 2018, and there was a significant difference at the probability level of $1 \%$. But in 2018 , due to the stability of the number of canes, the intensity of pruning was reduced and became stable. Vine vigor and viticulturaL practice of the grapes may also impact on grape anthocyanin concentration. The vigor parameters including main shoot length and total shoot length were positively correlated to yield; were negatively correlated with berry anthocyanin production (Baluja et al., 2012). The low number of shoots per canopy volume can lead to a reduction in the intensity and even to a complete cessation of various metabolic processes (Jones, 1992) which was concluded in the current work (data was not shown).

\section{CONCLUSIONS}

Phenolic constitutes possess a large quantity of biochemical properties from which grapes are their renowned source with undisputable importance in the daily diet of people worldwide. Whereas, pruning as a critical practice if adopted un appropriately like pruning all mature canes by local grape growers, heavy exploitation of stored nutritional material of the tree and therefore, reduction in vines vigourity, as well as quality, would be the aftermath. The results obtained are reliable proof that the pruning program can negative or positively influence phenolic compound concentration in grape. More, the grape cultivars show different sensitivity to the type of viticultural practice which was observed in 'Sahebi' and 'Halagho'. These findings are valuable to improve viticultural practices in grape production, allowing the improvement of grape quality to forecast the potential crop before pruning. Nonetheless, applying this pruning program on the same cultivars with other training systems further needs to be investigated. Additionally, the locality is another crucial factor that understands its effectiveness on these two cultivars is essential. Ultimately, the present work expands the knowledge of appropriate pruning and management on two Iranian red grape cultivars for grape growers.

\section{ACKNOWLEDGMENTS}

We thank the Department of Horticultural Sciences of the University of Guilan for supplying equipment to this study.

\section{REFERENCES}

1. Adams, D. O. Am. J. Enol. Vitic, 2006, 57(3): 249-256.

2. Ahmedullah, M., Himelric, D. C. Grape management, 1989, 383-471.

3. Archer, E., Strauss, H. C. S. Afri. J. Enol. Vitic, 1989, 10(2): 74-76.

4. Azuma, A. J. Hortic, 2018, 59-63.

5. Baluja, J., Diago, M. P., Goovaerts, P.,Tardaguila, J. Precision Agric, 2012, 13:457-472.

6. Barbagallo, M. G., Guidoni, S., Hunter, J. J. S. Afr. J. Enol. Vitic, 2011, 32: 129-136.

7. Battista, F., Tomasi, D., Porro, D., Caicci, F., Giacosa, S., Rolle, L. Italian J. Food 
Sci, 2015, 27: 136-141.

8. Bergqvist, J., Dokoozlian, N., Ebisuda, N. Amer. J. Enol. Viti, 2001, 52(1): 1-7.

9. Billikopf, G., Norton, M. California Agric, 1992, 46 (5): 12-13.

10. Boss, P. K., Davies, C., Robinson, S. P. Plant Physiol, 1996, 111(4):1059-1066.

11. Braidot, E., Zancani, M., Petrussa, E., Peresson, C., Bertolini, A., Patui, S., Macri, F., Vianello, A. Plant Signaling and Behav, 2008, 3: 626-632.

12. Casazza, A. A., Aliakbarian, B., Mantegna, S., Cravotto, G., Perego, P. J. Food Engi, 2010, 100: 50-55.

13. Costa, E., Cosme, F., Jordao AM, Mendes-Faia, A. Int. J vine and wine sci, 2014, 48:51-62.

14. Cote, J., Caillet, S., Doyon, G., Sylvain, J. F., Lacroix, M. Critical Rev. Food Sci. Nutri, 2010, 50: 872-888.

15. Dani, C., Oliboni, L. S., Vanderlinde, R., Bonatto, D., Salvador, M., Henriques, J. A. P. Food Chem. Toxic, 2007, 45: 25742580.

16. De Pascali, S. A., Coletta, A., Del Coco, L., Basile, T., Gambacorta G, Fanizzi, F.P. Food Chem, 2014, 161, 112-119.

17. Ferrandino, A., Lovisolo, C. Environ Experi Bot, 2013, 114-124.

18. Garrido, J., Borges, F. Food Res. Inter, 2013, 54:1844-1858.

19. Godevac, D., Tesevic, V., Velickovic, M., Vujisic, L. J., Vajs, V, Milosavljevic, S. J. Serb. Chem. Soc, 2010, 75: 1641-1652.

20. Gomez Gallego, M. A., Sanchez-Palomo E, Hermosın-Gutierrez I, Gonzales Vinas MA. J Europ. Food Res. Technol, 2013, 236:647-658.

21. Groumpos, P. P., Antigoni, A. P., Groumpos, P., Vasileios, P. IFACPapersOnLine, 2015, 48-24: 015-020.

22. Hogan, S., Zhang, L., Li, J., Zoecklein, B., Zhou, K. LWT - Food Sci. and Tech, 2009, 42: 1269-1274.

23. Intrigliolo, D. S., Castel, J. R. (2011). Irriga. Sci, 29:443-454.

24. Jones, H. G. Cam. Uni. Press, Cambridge, 1992

25. Katalinic, V., Smole Mozina, S., Skroza,
D., Generalic, I., Abramovic, H., Milos, M., Ljubenkov, I., Piskernik S, Pezo I, Terpinc P, Boban, M. Food Chem, 2010, 119: 715723.

26. Keller, M. The Science of Grapevines: Anatomy and Physiology. Acad. Press. 2015.

27. Keller, M. J. Grape and Wine Res, 2010, 16: $56-69$.

28. Longo, L., Vasapollo, G. Food Chem, 2006, 94(2), 226-231.

29. Mannini, F., Mollo, A., Lale Demoz, P. Agric Vitis, 2010, 127: 142-147.

30. McGovern, P., Jalabadze, M., Batiuk, S., Callahan, M. P., Smith, K. E., Hall, G. R., Kvavadze, E, Maghradze D, Rusishvili N, Bouby L, Failla O, Cola G, Mariani L, Boaretto E, Bacilieri R, This P, Wales, N, Lordkipanidze, D. Proce. Nation. Acad. of Sci, 2017, 114, 10309-E10318.

31. Montealegre, R. R., Peces, R. R., Vozmediano, J. L. C., Gascuena, J. M., Romero, E. G. J. Food Comp. Anal, 2006, 19(6-7): 687-693.

32. Myles, S., Boyko, A. R., Owens, C. L., Rown, P. J., Grassi, F., Aradhya, M. K., Prins, B., Reynolds, A., Chia, JM., Ware, D., Bustamante, C. D., Buckler, E. S. Proce. Nation. Acad. of Sci, 2011, 108 (9): 3530-3535.

33. Nile, S. H., Kim, S. H., Ko, E. Y, Park, S. W. BioMed Res Int, 2013, 71: 65-80.

34. Orak, H. H. Sci. Hort, 2007, 111: 235-241.

35. Pantelic, M. M., Zagorac, D. C. D., Davidovic, S. M., Todic, S. R., Beslic, Z. S., Gasic, U. M., Tesic, Z. L., Natic, M. M. Food Chem, 2016, 211: 243-252.

36. Paredes-Lopez, O., Cervantes-Ceja, M. L., Vigna-Perez, M., Hernandez-Perez, T. Plant Foods for Human Nutri, 2010, 65: 299-308.

37. Peneau, S., Hoehn, E., Roth, H. R., Escher, F., Nuessli, J. Food Qual. Pref. 17: $9-19$

38. Petrie, P. R., Trought, M. C. T., Howell, G. S., Buchan, G. D., Palmer, J. W. Amer. J. Enol. Vitic, 2009, 60 (2): 173-182.

39. Reynolds, A. G., Heuvel J. Am. J. Enol. Vitic, 2009, 60: 251-268. 
40. Rodriguez-Montealegre, R., RomeroPeces, R., Chacon-Vozmediano, J. L., Martinez Gascuena, J., Garcia-Romero, E. J. Food Comp. Anal, 2006, 19: 687693.

41. Rolle, L., Torchio, F., Zeppa, G., Gerbi, V. Amer. J. Enol. Vitic, 2009, 60:93-97.

42. Satisha, J., Ramteke, S. D., Shikhamany, S. D. Ind. J Horti, 2000, 57(1): 9-12.

43. Shinomiya, R., Fujishima, H., Muramoto, K., Shiraishi, M. Scientia Horti, 2015, 193: 77-83.

44. Singleton, V. L., Rossi, J. R. Amer. J. Enol. Vitic, 1965, 16: 144-158.

45. Song, J., Smart, R., Wang, H., Dambergs, B., Sparrow, A., Qian, M. C. Food Chem, 2015, 173: 424-431.
46. Spayd, S. E., Tarara, J. M., Mee, D. L., Ferguson, J. Amer. J. Enol. Vitic, 2002, 53(3): 171-182.

47. Wrolstad, R. E. Corvallis, Ore: Oregon Agric Expt Station Bull, 1976, 624.

48. Xia, E. Q., Deng, G. F., Guo, Y. J., Li, H. B. Int. J Mol. Sci, 2010, 11: 622-646.

49. Yang, J., Martinson, T. E., Liu, R. H. Food Chem, 2009, 116: 332-339.

50. Yonekura-Sakakibara, K., Nakayama, T., Yamazaki, M., Saito, K. Springer. New York: 2009, 169-190.

51. Zhang, A., Fang, Y., Li, X., Meng, J., Wang, H., Li, H. Mol, 2011, 16: 2846-2861

Table 1: Peel phenolic content of 'Sahebi' and 'Halagho' grapes pruned during the years 2017 and 2018

\begin{tabular}{lccccc}
\hline \multicolumn{5}{c}{ Peel phenolic content (mg/g DW) } \\
\hline Treatment & $\begin{array}{c}\text { Number of buds } \\
\text { per cane }\end{array}$ & Halagho & Sahebi & Halagho & Sahebi \\
\hline Moderately & $43.81 \mathrm{a}$ & $28.80 \mathrm{~d}$ & $19.10 \mathrm{e}$ & $12.00 \mathrm{e}$ \\
\hline pruned & 4 & $42.51 \mathrm{a}$ & $27.71 \mathrm{~d}$ & $20.5 \mathrm{e}$ & $14.40 \mathrm{e}$ \\
Severely pruned & 6 & $31.44 \mathrm{c}$ & $26.85 \mathrm{~d}$ & $23.90 \mathrm{e}$ & $12.10 \mathrm{e}$ \\
& 8 & $38.15 \mathrm{ab}$ & $29.10 \mathrm{~d}$ & $21.30 \mathrm{e}$ & $12.20 \mathrm{e}$ \\
\hline \multirow{2}{*}{ Lightly pruned } & 4 & $39.76 \mathrm{ab}$ & $27.45 \mathrm{~d}$ & $20.90 \mathrm{e}$ & $14.50 \mathrm{e}$ \\
& 6 & $34.00 \mathrm{bc}$ & $26.59 \mathrm{~d}$ & $25.50 \mathrm{e}$ & $14.00 \mathrm{e}$ \\
\hline
\end{tabular}

Meanes with the same letters in each column and row show no significant difference in Duncan's multiple range test at $p \leq 5 \%$. 
Table 2: Pulp phenolic content in 'Sahebi' and 'Halagho' grapes pruned during the years 2017 and 2018

\begin{tabular}{lccccc}
\hline \multicolumn{6}{c}{ Pulp phenolic content (mg/g DW) } \\
\hline Treatment & $\begin{array}{c}\text { Number of } \\
\text { buds per } \\
\text { cane }\end{array}$ & Halagho & Sahebi & Halagho & Sahebi \\
\hline Control & $\begin{array}{c}\text { Moderately } \\
\text { pruned }\end{array}$ & $4.05 \mathrm{bc}$ & $2.65 \mathrm{de}$ & $1.38 \mathrm{fg}$ & $0.61 \mathrm{~g}$ \\
\hline \multirow{3}{*}{ Severely pruned } & 4 & $3.68 \mathrm{bcd}$ & $3.29 \mathrm{~cd}$ & $0.94 \mathrm{fg}$ & $0.79 \mathrm{fg}$ \\
& 6 & $3.27 \mathrm{~cd}$ & $2.71 \mathrm{de}$ & $1.42 \mathrm{fg}$ & $0.72 \mathrm{fg}$ \\
& 8 & $5.14 \mathrm{a}$ & $2.70 \mathrm{de}$ & $1.10 \mathrm{fg}$ & $0.81 \mathrm{fg}$ \\
\hline \multirow{2}{*}{ Lightly pruned } & 4 & $3.29 \mathrm{~cd}$ & $2.89 \mathrm{cde}$ & $0.84 \mathrm{fg}$ & $0.84 \mathrm{fg}$ \\
& 6 & $3.05 \mathrm{cde}$ & $2.65 \mathrm{de}$ & $1.86 \mathrm{ef}$ & $0.80 \mathrm{fg}$ \\
& 8 & $4.56 \mathrm{ab}$ & $2.63 \mathrm{de}$ & $0.80 \mathrm{fg}$ & $1.17 \mathrm{fg}$ \\
\hline
\end{tabular}

Meanes with the same letters in each column and row show no significant difference in the Duncan's multiple range test at $p \leq 5 \%$.

Table 3: Total phenolic content of the whole berry in 'Sahebi' and 'Halagho' grapes pruned during the years 2017 and 2018

Total phenol content in the whole berry $(\mathrm{mg} / \mathrm{g} \mathrm{DW})$

\begin{tabular}{lccccc}
\hline & & & 2017 & \multicolumn{2}{c}{2018} \\
\hline Treatment & $\begin{array}{c}\text { Number of } \\
\text { buds per cane }\end{array}$ & Halagho & Sahebi & Halagho & Sahebi \\
\hline Control & $\begin{array}{c}\text { Moderately } \\
\text { pruned }\end{array}$ & 6.23 efgh & $4.60 \mathrm{i}$ & $7.74 \mathrm{bcdle}$ & $7.25 \mathrm{cdef}$ \\
\hline \multirow{2}{*}{ Severely pruned } & 4 & $5.50 \mathrm{hi}$ & $4.70 \mathrm{i}$ & $8.37 \mathrm{bc}$ & $8.12 \mathrm{bc}$ \\
& 6 & $5.63 \mathrm{ghi}$ & $4.48 \mathrm{i}$ & $10.00 \mathrm{a}$ & $7.28 \mathrm{cdef}$ \\
& 8 & $5.30 \mathrm{hi}$ & $4.62 \mathrm{i}$ & $7.02 \mathrm{cdefg}$ & $7.50 \mathrm{bcde}$ \\
\hline \multirow{3}{*}{ Lightly pruned } & 4 & $6.38 \mathrm{efgh}$ & $4.65 \mathrm{i}$ & $7.62 \mathrm{bcde}$ & $7.41 \mathrm{bcdef}$ \\
& 6 & $5.57 \mathrm{ghi}$ & $5.94 \mathrm{fghi}$ & $8.86 \mathrm{ab}$ & $7.92 \mathrm{bcd}$ \\
& 8 & $6.42 \mathrm{defgh}$ & $4.75 \mathrm{i}$ & $7.60 \mathrm{bcde}$ & $8.36 \mathrm{bc}$ \\
\hline
\end{tabular}

Meanes with the same letters in each column and row show no significant difference in Duncan's multiple range test at $p \leq 5 \%$. 
Table 4: Peel anthocyanin content in 'Sahebi' and 'Halagho' grapes pruned during the years 2017 and 2018

\begin{tabular}{lccccc}
\hline \multicolumn{6}{c}{ Peel anthocyanin content (mg/g DW) } \\
\hline Treatment & $\begin{array}{c}\text { Number of buds } \\
\text { per cane }\end{array}$ & Halagho & Sahebi & Halagho & Sahebi \\
\hline Control & $\begin{array}{c}\text { Moderately } \\
\text { pruned }\end{array}$ & $0.93 \mathrm{a}-\mathrm{c}$ & $0.95 \mathrm{a}-\mathrm{c}$ & $0.03 \mathrm{f}$ & $0.03 \mathrm{f}$ \\
\hline \multirow{3}{*}{ Severely pruned } & 4 & $1.07 \mathrm{a}$ & $0.78 \mathrm{~b}-\mathrm{e}$ & $0.04 \mathrm{f}$ & $0.04 \mathrm{f}$ \\
& 6 & $0.88 \mathrm{a}-\mathrm{d}$ & $0.62 \mathrm{de}$ & $0.03 \mathrm{f}$ & $0.11 \mathrm{f}$ \\
& 8 & $1.00 \mathrm{ab}$ & $0.63 \mathrm{de}$ & $0.03 \mathrm{f}$ & $0.04 \mathrm{f}$ \\
\hline \multirow{3}{*}{ Lightly pruned } & 4 & $0.69 \mathrm{c}-\mathrm{e}$ & $0.97 \mathrm{ab}$ & $0.03 \mathrm{f}$ & $0.04 \mathrm{f}$ \\
& 6 & $1.09 \mathrm{a}$ & $0.55 \mathrm{e}$ & $0.04 \mathrm{f}$ & $0.03 \mathrm{f}$ \\
& 8 & $0.94 \mathrm{a}-\mathrm{c}$ & $0.74 \mathrm{~b}-\mathrm{e}$ & $0.03 \mathrm{f}$ & $0.04 \mathrm{f}$ \\
\hline
\end{tabular}

Meanes with the same letters in each column and row show no significant difference in Duncan's multiple range test at $p \leq 5 \%$.

Table 5: Pulp anthocyanin content in 'Sahebi' and 'Halagho' grapes pruned during the years 2017 and 2018

\begin{tabular}{lccccc}
\hline \multicolumn{5}{c}{ Pulp anthocyanin content (mg/g DW) } \\
\hline Treatment & $\begin{array}{c}\text { Number of buds } \\
\text { per cane }\end{array}$ & Halagho & Sahebi & Halagho & Sahebi \\
\hline Control & $\begin{array}{c}\text { Moderately } \\
\text { pruned }\end{array}$ & $0.48 \mathrm{c}$ & $0.51 \mathrm{c}$ & $0.007 \mathrm{~d}$ & $0.001 \mathrm{~d}$ \\
\hline \multirow{3}{*}{ Severely pruned } & 4 & $0.62 \mathrm{bc}$ & $0.55 \mathrm{c}$ & $0.003 \mathrm{~d}$ & $0.011 \mathrm{~d}$ \\
& 6 & $0.86 \mathrm{a}$ & $0.52 \mathrm{c}$ & $0.006 \mathrm{~d}$ & $0.002 \mathrm{~d}$ \\
& 8 & $0.49 \mathrm{c}$ & $0.70 \mathrm{~b}$ & $0.004 \mathrm{~d}$ & $0.043 \mathrm{~d}$ \\
\hline \multirow{3}{*}{ Lightly pruned } & 4 & $0.48 \mathrm{c}$ & $0.55 \mathrm{c}$ & $0.001 \mathrm{~d}$ & $0.005 \mathrm{~d}$ \\
& 6 & $0.49 \mathrm{c}$ & $0.51 \mathrm{c}$ & $0.001 \mathrm{~d}$ & $0.006 \mathrm{~d}$ \\
& 8 & $0.51 \mathrm{c}$ & $0.51 \mathrm{c}$ & $0.003 \mathrm{~d}$ & $0.003 \mathrm{~d}$ \\
\hline
\end{tabular}

Meanes with the same letters in each column and row show no significant difference in Duncan's multiple range test at $p \leq 5 \%$. 
Table 6: Total anthocyanin content in 'Sahebi' and 'Halagho' grapes pruned during the years 2017 and 2018

\begin{tabular}{lccccc}
\hline \multicolumn{5}{c}{ Total anthocyanin content $(\mathrm{mg} / \mathrm{g} \mathrm{DW})$} \\
\hline Treatment & $\begin{array}{c}\text { number of buds } \\
\text { per cane }\end{array}$ & Halagho & Sahebi & Halagho & Sahebi \\
\hline control & moderately pruned & $0.51 \mathrm{a}$ & $0.33 \mathrm{c}$ & $0.031 \mathrm{~d}$ & $0.024 \mathrm{~d}$ \\
\hline \multirow{3}{*}{ Severely pruned } & 4 & $0.38 \mathrm{a}-\mathrm{c}$ & $0.40 \mathrm{a}-\mathrm{c}$ & $0.030 \mathrm{~d}$ & $0.031 \mathrm{~d}$ \\
& 6 & $0.48 \mathrm{ab}$ & $0.34 \mathrm{bc}$ & $0.030 \mathrm{~d}$ & $0.092 \mathrm{~d}$ \\
& 8 & $0.43 \mathrm{a}-\mathrm{c}$ & $0.37 \mathrm{bc}$ & $0.023 \mathrm{~d}$ & $0.026 \mathrm{~d}$ \\
\hline \multirow{3}{*}{ Lightly pruned } & 4 & $0.48 \mathrm{ab}$ & $0.35 \mathrm{bc}$ & $0.027 \mathrm{~d}$ & $0.026 \mathrm{~d}$ \\
& 6 & $0.34 \mathrm{bc}$ & $0.36 \mathrm{bc}$ & $0.028 \mathrm{~d}$ & $0.026 \mathrm{~d}$ \\
& 8 & $0.38 \mathrm{a}-\mathrm{c}$ & $0.28 \mathrm{c}$ & $0.025 \mathrm{~d}$ & $0.028 \mathrm{~d}$ \\
\hline
\end{tabular}

Meanes with the same letters in each column and row show no significant difference in Duncan's multiple range test at $p \leq 5 \%$. 